\title{
"The impact of packaging on consumer behavior in the private label market - the case of Slovak consumers under 25 years of age"
}

\begin{tabular}{|c|c|}
\hline AUTHORS & $\begin{array}{l}\text { Zdenka Kádeková (D https://orcid.org/0000-0003-2814-5239 } \\
\text { Ingrida Košičiarová (D https://orcid.org/0000-0003-3763-0826 } \\
\text { Vladimir Vavřečka (D https://orcid.org/0000-0001-6534-3379 } \\
\text { Milan Džupina (D https://orcid.org/0000-0003-0230-6583 }\end{array}$ \\
\hline ARTICLE INFO & $\begin{array}{l}\text { Zdenka Kádeková, Ingrida Košičiarová, Vladimir Vavřečka and Milan Džupina } \\
\text { (2020). The impact of packaging on consumer behavior in the private label } \\
\text { market - the case of Slovak consumers under } 25 \text { years of age. Innovative } \\
\text { Marketing, } 16(3), 62-73 \text {. doi:10.21511/im.16(3).2020.06 }\end{array}$ \\
\hline DOI & http://dx.doi.org/10.21511/im.16(3).2020.06 \\
\hline RELEASED ON & Friday, 07 August 2020 \\
\hline RECEIVED ON & Monday, 04 May 2020 \\
\hline ACCEPTED ON & Thursday, 23 July 2020 \\
\hline LICENSE & $\begin{array}{l}(\mathrm{coc}) \mathrm{EY} \\
\text { This work is licensed under a Creative Commons Attribution } 4.0 \text { International } \\
\text { License }\end{array}$ \\
\hline JOURNAL & "Innovative Marketing " \\
\hline ISSN PRINT & $1814-2427$ \\
\hline ISSN ONLINE & $1816-6326$ \\
\hline PUBLISHER & LLC "Consulting Publishing Company "Business Perspectives" \\
\hline FOUNDER & LLC "Consulting Publishing Company "Business Perspectives" \\
\hline
\end{tabular}

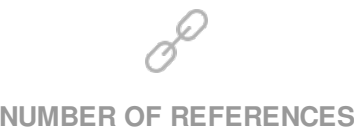

48

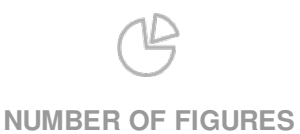

2

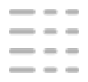

NUMBER OF TABLES

5

(C) The author(s) 2022. This publication is an open access article. 


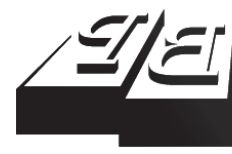

\section{BUSINESS PERSPECTIVES}

()

LLC "CPC "Business Perspectives"

Hryhorii Skovoroda lane, 10,

Sumy, 40022, Ukraine

www.businessperspectives.org

Received on: $4^{\text {th }}$ of May, 2020

Accepted on: $23^{\text {rd }}$ of July, 2020

Published on: $7^{\text {th }}$ of August, 2020

(c) Zdenka Kádeková, Ingrida Košičiarová, Vladimír Vavrečka, Milan Džupina, 2020

Zdenka Kádeková, Assistant Professor, Ing., PhD., Department of Marketing and Trade, Faculty of Economics and Management, Slovak University of Agriculture in Nitra, Slovakia.

Ingrida Košičiarová, Assistant Professor, Ing., PhD., Department of Marketing and Trade, Faculty of Economics and Management, Slovak University of Agriculture in Nitra, Slovakia.

Vladimír Vavrečka, Head of the Department of Marketing, Ing., CSc., Department of Marketing, University of Entrepreneurship and Law, Czech Republic. (Corresponding author)

Milan Džupina, Associate Professor, doc., Ing., PhD., Department of Mass Media Communication and Advertising, Faculty of Philosophy, Constantine the Philosopher University in Nitra, Slovakia.
Zdenka Kádeková (Slovakia), Ingrida Košičiarová (Slovakia),

Vladimír Vavrečka (Czech Republic), Milan Džupina (Slovakia)

\section{THE IMPACT OF PACKAGING} ON CONSUMER BEHAVIOR IN THE PRIVATE LABEL MARKET THE CASE OF SLOVAK CONSUMERS UNDER 25 YEARS OF AGE

\begin{abstract}
Although there were many consumer behavior studies, their focus was on traditional brands. Despite that, their conclusions and recommendations can serve as a model for private label research. This paper aims to find out the influence of packaging on consumer purchasing decisions in the yoghurt segment. Attention was drawn to Slovak consumers under the age of 25 years. To achieve the aim, survey, structured questionnaire (549 randomly chosen respondents) and blind test (20 respondents) methods were used. For a deeper analysis, four hypotheses were set out and tested using statistical methods of Pearsons' Chi-Square Test, Friedman test, Mantel-Haenszel Chi-Square Test, Phi Coefficient, Cramer's V Coefficient and correspondence analysis. The results proved that almost $58 \%$ of respondents bought private labels sporadically, over $20 \%$ of respondents bought them multiple times a week, and over $18 \%$ of respondents bought them once a week. In terms of perceived quality, it can be said that quality of private label products is perceived as good and adequate, they evoke impression of adequate quality at a reasonable price, the decisive factor for their purchase is a combination of reasonable price and quality, and the reasons not to buy are high price, low quality and lack of information about the producer. Regarding the impact of packaging on respondents' purchasing decisions, it is found that less than $34 \%$ of respondents believe that packaging of private label products is unattractive, and up to $33 \%$ of respondents think that packaging does not affect them.
\end{abstract}

\section{Keywords}

JEL Classification

private label, consumer preference, yoghurt, factors leading to purchase, young consumers

M31, M39

\section{INTRODUCTION}

The current retail revolution, which, as the 2018 Nielsen Report says, has a significant impact on the food industry worldwide, is mainly characterized by the development of one global phenomenon called private labels (Herstein \& Gamliel, 2004; Smith \& Bashaw, 2009; Kakkos, Trivellas, \& Sdrolias, 2015). Simply put, private labels represent a strategy for labeling traditional brand products with the retailer's brand, using his own name, or the name/brand that he owns (Košičiarová \& Nagyová, 2014). This strategy was introduced in the USA at the end of the nineteenth century mainly to simplify the consumer's purchasing decision, the need to offer an alternative purchasing option for more cost-sensitive customers, respectively strengthening the market position in a competitive environment (Nagyová \& Košičiarová, 2014). It follows that private labels do not constitute a "novelty", but the focus is on them, especially in the current competitive and, above all, dynamic market environment (Polakevičová, 2015; Džupina, Hodinková, \& Kiková, 2016; Mach, Dvořák, \& Hošková, 
2018; Lorincová, Hitka, Štarchoň, \& Stachová, 2018; Balcarová, Pokorná, \& Pilař, 2014; Kádek, 2014), when we begin to realize their hidden advantages - an alternative purchasing for more cost-sensitive customers, the possibility of increasing sales not only for producers but also retailers, strengthening their own name or brand, etc.

This paper focuses on consumer preferences in the context of loyalty to the brand of selected food products in the yoghurt segment (as several studies have shown that private labels are purchased primarily in the categories of milk and dairy products (e.g., research by Košičiarová, Nagyová, Holienčinová, Kádeková, \& Rybanská, 2018)), with the focus on respondents under the age of 25 because, according to several surveys (e.g., Polakevičová and Uhríková, 2015; Bulanda, Džupina, \& Franková, 2018a; Bulanda, Viteková, Koprda, \& Blahová, 2018b; Šedík, Horská, Skowron-Grabowska, \& Illés, 2018a; Šedík, Kňazovická, Horská, \& Kačániová, 2018b), they represent potential customers, who may eventually become loyal buyers who prefer the brand. While consumer preferences for the brand have been investigated, that is, whether they prefer a traditional brand over a private brand, dairy yoghurts, namely two traditional-brand yoghurts and three private-brand yoghurts, were blind tested. An unusual feature of this research is that identical products were tested in a blind test, i.e. traditional brand with its private alternative.

\section{LITERATURE REVIEW}

As indicated in the introduction, private labels are an alternative to purchasing, which has been on the market for quite a long time but has not received much attention recently. There may be several reasons, but perhaps the most important is that individual market players (i.e., manufacturers, retailers and consumers) are beginning to realize their hidden advantages - their lower price compared to traditional brands and the increased quality of such labeled products. In many ways, private labels are considered to be more profitable not only at lower production costs but also at lower costs of research and development, promotion, sales promotion, advertising, as well as physical distribution itself (Kotler \& Keller, 2007). This is possible, in part, due to the use of branded products as their "model" or inspiration (Tvrdoň \& Přibyl, 2004), which is subsequently reflected in the price and means that a private label trader can charge a lower price for his product while achieving a higher profit margin (Nagyová \& Košičiarová, 2014).

While a trademark is a label or part of a label that protects the seller's exclusive rights to use its name or emblem (Rajt, 2000), a private label is a brand whose creation, planning and development are under the control of retail or other retail market players (Horská, 2007). In other words, while the manufacturer owns "traditional" brands (trademarks), retail chains own private labels.
Nowadays, customers are surrounded by a large number of different brands. If consumers think that most brands provide identical characteristics, i.e. there are minimal quality differences between brands; one can talk about brand parity. For consumers, this means that they do not buy goods from only one particular brand, but from a group of acceptable brands. Therefore, their buying decisions are dependent on criteria such as availability, price or a particular product-specific offer, not just quality, as it was previously assumed. As a result of this process, customer loyalty to a specific brand decreases significantly (Clow \& Baack, 2008).

Although traditional brands are still dominant in the current competitive market, private labels are gradually progressing and tend to take over (Chimhundu, 2011; Ruiz-Real, Gázquez-Abad, Esteban-Millat, \& Martinez-Lopez, 2016). Several studies on private labels show that while seven out of ten buyers in the USA have already purchased a private label product, they consider its quality to be comparable, if not higher, to traditional brands (Park City Group, 2000). In the case of Europe, this number is even higher, as the share of private label purchases in its countries increases from year to year. Currently, their percentage of purchases in the 17 European countries is perhaps over $30 \%$. It is interesting to note that in the case of 'leaders', such as Spain, Switzerland and the United Kingdom, the share is up to $50 \%$ or more. According to Brian Sharoff (note - President of PLMA), "Recent data 
published by Nielsen declares that the popularity of private labels across Europe is enormous. While for countries such as Spain and Switzerland, every other product purchased is a private label product, for the remaining 17 countries surveyed it is every third product purchased." (PLMA, 2019).

The consumer as such is perceived as an end-user or a user of a product, unlike a customer who purchases goods or services but does not consume them (Bulanda et al., 2018a; Bulanda et al., 2018b; Pilař, Kvasničková Stanislavská, Gresham, Poláková, Rojík, \& Petkov, 2018). The primary goal of every single business, regardless of its focus, is to attract new, potential customers, as the customer is the one who creates the demand for goods and services and is very likely to eventually become a loyal consumer over time or customer who becomes loyal not only to the operation itself but above all to its brand. In doing so, companies compete primarily by promoting and lowering prices to attract the largest possible customer base (Kenton, 2018; Světlík, Bulanda, 2019; Štarchoň and Weberová, 2019; Janková \& Strbová, 2017; Kaliji, Mojaverian, Amirnejad \& Canavari, 2019).

The aim of foreign as well as domestic business companies is to reach all customer groups, which means that they want to satisfy not only those price-sensitive customers but also those who prefer buying high-quality products. All these requirements are to be met by private label products, whose share in Europe, and especially in Slovakia, is continuously growing (Košičiarová, Holienčinová, \& Nagyová, 2014).

\section{AIM, METHODOLOGY AND HYPOTHESES}

This paper aims to find out how packaging affects consumer purchasing decisions in the yoghurt segment, with the focus on Slovak consumers under 25 years of age. Research, anonymous questionnaire and blind test methods were used to achieve the above goal. The questionnaire survey was conducted from April to May 2019 on a sample of 549 randomly selected respondents (their basic characteristics are shown in Table 1). The blind test was then conducted in May 2019 on a sample of 20 respondents who tested a total of four yoghurts - two traditional yoghurts (samples 2 and 4) and three private yoghurts (samples 1,3 , and 5).

The questionnaire covered the whole territory of Slovakia and represented all regions. The survey was distributed online and consisted of a total of 17 questions divided into two parts - the first part consisted of questions focused on the issue, and the second part consisted of classification questions. Random sampling was used to ensure the representativeness of the sample - the sample of respondents can be considered as representative at the $95 \%$ confidence level and 5\% error margin as $n \geq 384$. The questionnaire was evaluated using pivot tables prepared in Microsoft Office Excel, based on which graphs were subsequently created.

\section{Table 1. Characteristics of respondents}

Source: Research results, 2019

\begin{tabular}{|c|c|c|c|}
\hline $\begin{array}{l}\text { Category of } \\
\text { respondents }\end{array}$ & Count & $\begin{array}{c}\text { Place of residence of } \\
\text { respondents }\end{array}$ & Count \\
\hline Male & 185 & City & 345 \\
\hline Female & 364 & Countryside & 204 \\
\hline $\begin{array}{l}\text { Net household } \\
\text { income }\end{array}$ & Count & $\begin{array}{c}\text { Educational structure } \\
\text { of respondents }\end{array}$ & Count \\
\hline Under 500 EUR & 88 & Primary education & 23 \\
\hline $501-800$ EUR & 81 & $\begin{array}{l}\text { Secondary education } \\
\text { without graduation }\end{array}$ & 17 \\
\hline $801-1.100$ EUR & 136 & $\begin{array}{l}\text { Secondary education } \\
\text { with graduation }\end{array}$ & 226 \\
\hline $1.101-1.500$ EUR & 102 & $\begin{array}{l}\text { Higher education } \\
\text { (I degree) }\end{array}$ & 245 \\
\hline \multirow[t]{2}{*}{ Over 1.501 EUR } & 142 & $\begin{array}{l}\text { Higher education } \\
\text { (Il degree) }\end{array}$ & 36 \\
\hline & & Other & 2 \\
\hline $\begin{array}{c}\text { Economic activity } \\
\text { of respondents }\end{array}$ & Count & $\begin{array}{c}\text { Number of household } \\
\text { members }\end{array}$ & Count \\
\hline Student & 373 & One member & 73 \\
\hline Employed & 147 & Two members & 94 \\
\hline Unemployed & 7 & Three members & 133 \\
\hline Entrepreneur & 13 & Four members & 194 \\
\hline \multirow[t]{2}{*}{ Maternity leave } & 9 & Five members & 1 \\
\hline & & Other & 56 \\
\hline
\end{tabular}

Table 2. Examined chocolate yoghurts and their designations

Source: Research results, 2019

\begin{tabular}{l|c}
\hline \multicolumn{1}{c}{ Sample designation } & Examined yoghurt \\
\hline Sample 1 & Billa additive-free yoghurt \\
Sample 2 & $\begin{array}{c}\text { Bánovecký additive-free } \\
\text { yoghurt }\end{array}$ \\
\hline Sample 3 & Z lásky k tradícii \\
\hline Sample 4 & Zvolenský cream yoghurt \\
\hdashline Sample 5 & Lidl cream yoghurt \\
\hline
\end{tabular}


The data were processed using Microsoft Excel and then evaluated in the XL Stat or SAS Enterprise Guide and SAS 9.4. The formulated hypotheses were tested using statistical methods such as Pearsons' Chi-Square Test, Mantel-Haenszel Chi-Square Test, Friedman Test, Phi Coefficient, Cramer's V Coefficient and Correspondence Analysis.

If the $p$-value is less than the significance level when testing hypotheses, for the XL Stat software it is 0.05 , the null hypothesis is rejected and the alternative hypothesis is confirmed (Witek, 2016).

For the sake of a more in-depth and more detailed analysis of the set objectives, the following hypotheses were formulated:

H1: It is assumed that there is a relationship between buying private labels and the gender of respondents.

H2: It is assumed that there is a relationship between the quality rating of private labels and the gender of respondents.

H3: It is assumed that there is a correlation between the perception of private label packaging and the gender of respondents.

H4: It is assumed that there is a dependence between what will affect respondents to purchase private label products and their gender.

H5: It is assumed that there is a correlation between the decisive factor when buying private labels and the gender of respondents.

H6: It is assumed there is a link between what discourages respondents from buying private labels and their gender.

\section{EMPIRICAL RESULTS}

Many experts and researches point out (e.g., Habánová, Lorková, \& Kopčeková, 2010; Dudriková, Nagyová, \& Dičáková, 2017; Kubicová, Predanocyová, \& Kádeková, 2019), that milk and dairy products are valuable foods that have a beneficial effect on consumer health. These products can be classified as so-called functional foods that provide the consumer with a full range of beneficial substances for both immunity and vitality, in addition to saturation. In terms of the current value of milk and dairy products consumption in Slovakia (at $174.6 \mathrm{~kg}$ in 2017 (Statistical Office of the SR, 2018)), it can be said that the given use is significantly lower than the recommended dose of milk and dairy products, i.e., $220 \mathrm{~kg}$ per capita per year (Košičiarová et al., 2018). Besides, the last value meeting the recommended dose of consumption was recorded in Slovakia in 1990.

Even though the consumption of milk and dairy products has been on a generally declining trend over recent decades, statistics of the average consumption of yoghurt in $\mathrm{kg} /$ inhabitant tends to grow every year and shows an increase of $4 \mathrm{~kg} /$ capita/year, that, despite the non-compliance with the recommended dose of dairy products, shows the increasing interest of Slovak consumers in consumption of fermented milk products, in particular, yoghurts (note - according to VÚEPP data from 2011 to 2018, the average annual consumption of yoghurts increased from $7 \mathrm{~kg} / \mathrm{capita} /$ year in 2010 to $10.2 \mathrm{~kg} / \mathrm{capita} /$ year in 2017).

For the above mentioned reason, yoghurts became the research issue, and the focus was on two samples of yoghurts sold under the traditional brand (samples 2 and 4) and three samples of yoghurts sold under the private label (samples 1, 3 and 5). As mentioned above, the concern of the research is that these were identical yoghurts, i.e., a traditional yoghurt brand and its private-label alternative. The research, questionnaire and blind test methods mentioned above have been chosen as research methods, using which it was examined how the packaging affects the purchasing decision of consumers under the age of 25 in the yoghurt segment. As Table 1 shows, a total of 549 respondents participated in the research, most of whom were women (66.30\% of respondents), students (67.94\% of respondents), respondents with completed first degree higher education (44.63\% of respondents) or respondents with secondary education with graduation (41.17\% of respondents), respondents with net monthly household income over $€ 1.501$ (25.87\% of respondents), respondents with four household members (34.97\% of respondents) and respondents from the city ( $62.84 \%$ of respondents). 


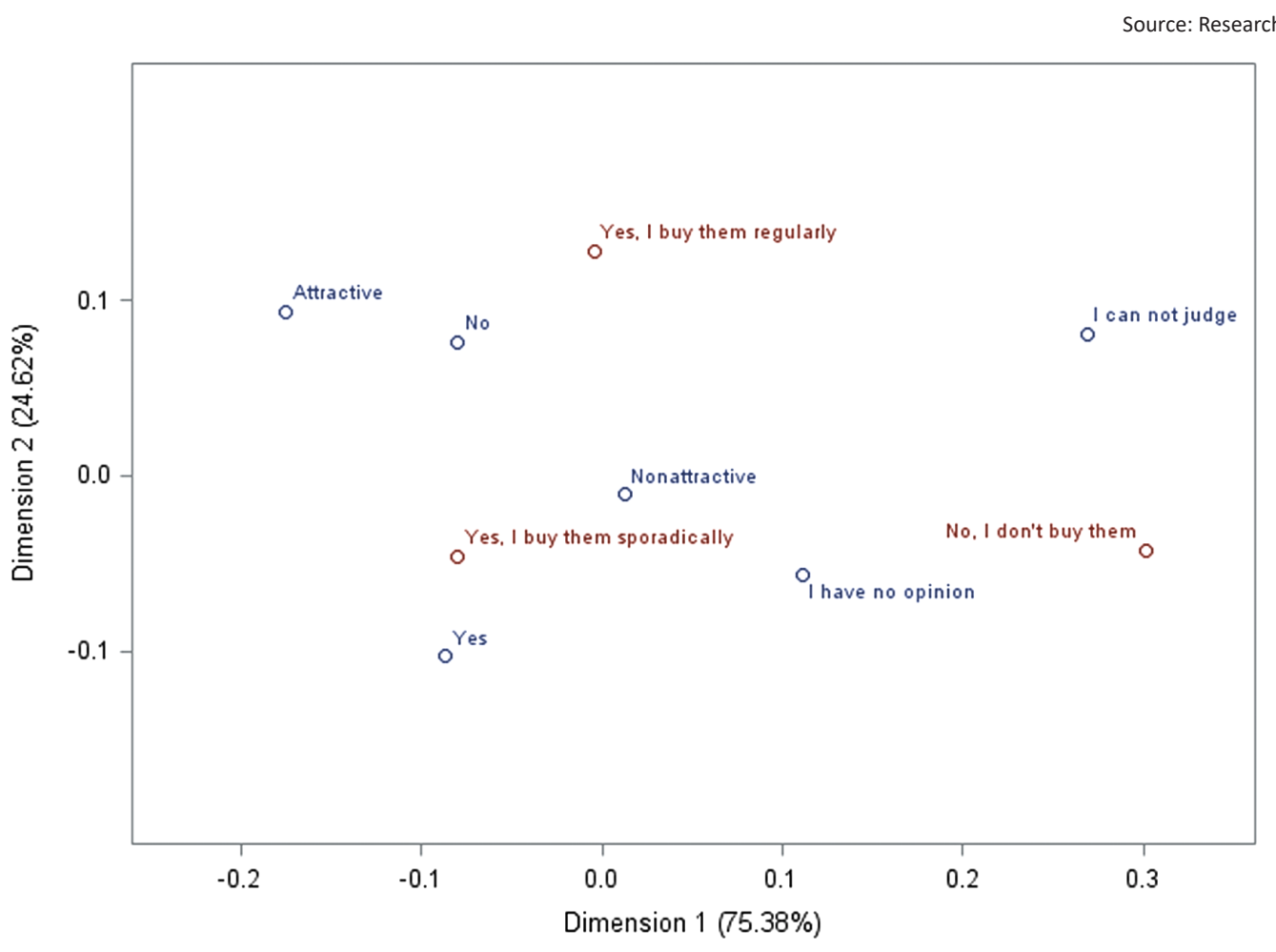

Figure 1. Correspondence analysis

The results of the research can be perceived more than positively, as it was found out that although they are relatively young respondents who do not yet have to support their families and do not have to think about their expenses, their answer to the question of buying private label products was positive - up to $26.41 \%$ of respondents buy them regularly, and $57.92 \%$ of respondents buy them sporadically. In terms of their purchase frequency, it can be said that they buy them quite often, as $20.40 \%$ of respondents stated that they buy them multiple times a week, $18.21 \%$ of respondents said they buy them once a week and $17.67 \%$ of respondents reported that they buy them multiple times a month. The most frequently reported response was "once a month", reported by $27.32 \%$ of respondents.

In terms of the perception of the quality of private label products, what they evoke in consumers, or the reasons for their purchase or non-purchase, several basically positive findings can be observed, as the respondents perceive private label products as products of good and adequate quality (47.18\% respondents), most of them, i.e. 59,74\% of respondents, have the impression of proper quality at a reasonable price, the decisive factor on which they buy is a combination of reasonable price and quality (47.72\% of respondents) and not price, as it was until recently (note: Burt research (2000) and Kumar and Steenkamp (2007); in this case, only $15.85 \%$ of respondents report price), and the reasons why they do not buy them are their high price (20.04\% of respondents), low quality (17.12\% of respondents) and lack of familiarity with their manufacturer (13.84\% of respondents).

As mentioned several times above, the paper also aims to find out how packaging affects consumers' purchasing decisions. Therefore, the study focuses on questions about how respondents perceive the packaging of private label products, or if they think that packaging influences their purchasing decision. The evaluation of these questions shows that although most respondents have no opinion on the packaging of private label products (up to $38.98 \%$ of respondents), up to $33.70 \%$ think that this packaging is unattractive, and up to $32.97 \%$ believe that their packaging does not affect them. Concerning the above, a correspondence analysis in SAS 9.4 was conducted to determine if the packaging influenced respondents' purchasing decisions. As can be seen from Figure 1, those respondents who reported that they regularly buy private labels think that private labels have attrac- 
Table 3. Friedman test results

\begin{tabular}{lc}
\hline \multicolumn{2}{c}{ Friedman test } \\
\hline Q (Observed value) & 350.588 \\
\hline Q (Critical value) & 16.919 \\
\hline DF & 9 \\
\hline$p$-value (Two-tailed) & $<0.0001$ \\
\hline Alpha & 0.05
\end{tabular}

\begin{tabular}{|c|c|c|c|c|c|c|c|}
\hline Sample & Frequency & Sum of ranks & Mean of ranks & \multicolumn{4}{|c|}{ Groups } \\
\hline [Milk and dairy products] & 549 & 2381.00 & 4.337 & A & - & - & - \\
\hline [Mineral waters, lemonades, juices] & 549 & 2523.50 & 4.597 & A & - & - & - \\
\hline [Confectionery] & 549 & 2873.50 & 5.234 & - & B & - & - \\
\hline [Salty snacks] & 549 & 3001.50 & 5.467 & - & $\mathrm{B}$ & - & - \\
\hline [Coffee, tea] & 549 & 3022.00 & 5.505 & - & $B$ & C & - \\
\hline [Meat and fish] & 549 & 3025.50 & 5.511 & - & B & C & - \\
\hline [Delicacies] & 549 & 3093.00 & 5.634 & - & B & C & - \\
\hline [Ready meals] & 549 & 3320.00 & 6.047 & - & - & C & $\mathrm{D}$ \\
\hline [Alcoholic drinks] & 549 & 3456.50 & 6.296 & - & - & - & $\mathrm{D}$ \\
\hline [Frozen semi-finished products] & 549 & 3498.50 & 6.372 & - & - & - & $\mathrm{D}$ \\
\hline
\end{tabular}

tive packaging and that the packaging does not affect them in their purchasing decision; respondents who buy private labels sporadically think that their packaging is unattractive and that it affects their purchasing decisions; and those respondents who do not buy them do not have an opinion and cannot asses it.

These findings are followed by a blind test conducted on a sample of 20 respondents from the category of young people, i.e., up to 25 years. Creamy yoghurts (Table 2) became the subject of the blind test as several studies have shown that private labels are purchased primarily in the categories of milk and dairy products (e.g., research by Košičiarová et al., 2018), and, for example, the current study, where the results of Friedman test clearly show that the most frequently bought private label products among respondents are milk and dairy products, as well as mineral water, lemonade and juice. Among the least often purchased products labeled with a private label, respondents included products such as alcoholic beverages and frozen semi-finished products (Table 3 ).

The blind test took place in two separate rounds in the first round, the respondents tasted yoghurts without knowing what yoghurt it was, and in the second round, they tasted yoghurts by seeing their particular packaging. This study aims to find out to what extent the product packaging influences the consumer's purchasing decision. Respondents were asked to evaluate selected attributes of the examined yoghurt on a scale of 1 to 5 , with 1 being the best rating and 5 the worst. In the first test, these attributes were color, aroma, consistency or yoghurt density, taste and proportion of chocolate. The packaging size (i.e., whether it is satisfactory for respondents) and the attractiveness of the packaging were added to the attributes in the second round of testing.

The results of both mentioned blind tests revealed interesting findings - while in the first round of the blind test, according to the overall assessment of the respondents, the best results were obtained for sample 5 and sample 3 , in the second round the best results were obtained for samples 5 and 4 (Figure 2).

Looking at the evaluation of the yoghurts in more detail, one finds that in the first round while comparing samples 1 and 2, representing identical yoghurts, sample 2 had the better color. The other attributes were perceived and evaluated almost identically, except that the taste was evaluated somewhat better in sample 1 and the aroma in sample 2. For samples 3 to 5 (representing identical yoghurts), respondents reported approximately the same ratings, but in terms of the proportion of chocolate, samples 4 and 5 were worse. In the second round of testing, when the respondents knew specific yoghurts and could, therefore, be influenced not only by the packaging but also by a particular brand, while comparing samples 1 and 

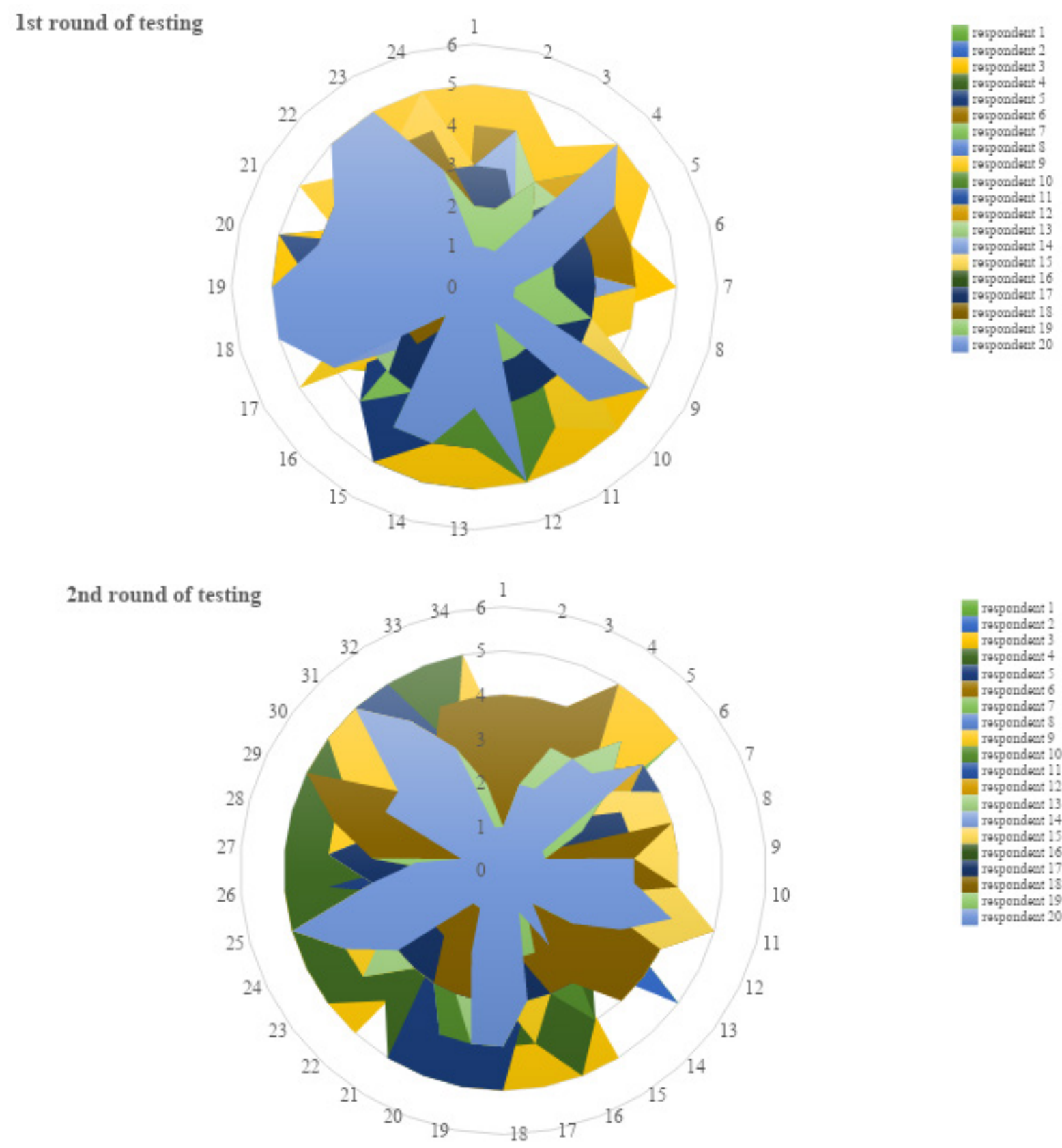

Figure 2. Blind test results

2 , sample 1 received a better color evaluation and sample 2 received a better taste and weight evaluation. When comparing samples 3 to 5 , sample 3 was best rated in terms of packaging attractiveness, sample 4 in terms of taste, sample 5 in flavor, and samples 4 and 5 in terms of consistency.

In terms of evaluating the attractiveness of packaging, or the impact of packaging on consumer behavior, it can be said that in this case, the irra- tional reasons prevail over the rational ones. As already mentioned, identical yoghurts under different brands were examined in the blind test and yet, respondents felt differences in taste, consistency, etc. This indicates that packaging can really influence the consumer's decision and plays an essential role in the purchasing decision and evaluation (note: the most attractive packaging in research was obviously the packaging with traditional, i.e. Slovak, motifs and patterns). 
The last question of the questionnaire survey was focused on what would most affect the respondents when purchasing private label products. Based on the evaluation of the question, it can be said that even the respondents were respondents from the young generation of consumers, that is, respondents under 25 years of age, the most frequently mentioned answers were mainly traditional forms of marketing communication, such as recommendations of acquaintances ( $40.62 \%$ of respondents), tasting (16.21\% of respondents) and free samples (or 1 +1 sale) and a more interesting form of promotion (both equally $15.12 \%$ of respondents).

\section{EVALUATING TESTED DEPENDENCIES}

H1: It is assumed that there is a relationship between buying private labels and the gender of respondents - rejected (as the p-value was higher than 0.05; exactly 0.1864).

H2: It is assumed that there is a relationship between the quality rating of private labels and the gender of respondents - confirmed.

H3: It is assumed that there is a correlation between the perception of private label packaging and the gender of respondents - rejected (as the p-value was higher than 0.05; exactly 0.5178).

H4: It is assumed that there is a dependence between what will affect respondents to purchase private label products and their gender - rejected (as the p-value was higher than 0.05; exactly 0.7291).

H5: It is assumed that there is a correlation between the decisive factor when buying private labels and the gender of respondents - confirmed.

H6: It is assumed that there is a link between what discourages respondents from buying private labels and their gender - rejected (as the p-value was higher than 0.05; exactly 0.1062).

As can be seen from the evaluation of the hypotheses formulated, only hypotheses 2 and 5 , which talk about the interdependence between the eval- uation of the quality of private labels and the gender of the respondents, and accordingly the dependence between the decisive factor when buying private labels and the gender of the respondents, were confirmed. These dependencies also illustrate the SAS Enterprise Guide outcomes listed in Tables 4 and 5. However, as can be seen from the tables, these dependencies are rather weak than moderate but still statistically significant (as the p-value was less than 0.05 at the significance level $\alpha$ and Phi coefficient, respectively, the values of the Crammer V coefficient were equal to 0.1811 and 0.1742).

Table 4. Dependence between the quality rating of private labels and the gender of respondents

\begin{tabular}{c|c:c:c} 
& \multicolumn{3}{c}{ Source: Research results, 2019. } \\
\hline Statistics & DF & Value & Prob \\
\hline Chi-square & 4 & 18.0022 & 0.0012 \\
\hline Likelihood Ratio Chi-Square & 4 & 17.7970 & 0.0014 \\
\hline Mantel-Haenszel Chi-Square & 1 & 1.4421 & 0.2298 \\
\hline Phi Coefficient & - & 0.1811 & - \\
\hdashline Contingency Coefficient & - & 0.1782 & - \\
\hdashline Cramer's V & - & 0.1811 & - \\
\hline
\end{tabular}

Table 5. Dependence between the decisive factor in the purchase of private labels and the gender of respondents

Source: Research results, 2019.

\begin{tabular}{l|c:c:c}
\hline \multicolumn{1}{c}{ Statistics } & DF & Value & Prob \\
\hline Chi-Square & 5 & 16.6665 & 0.0052 \\
\hdashline Likelihood Ratio Chi-Square & 5 & 16.8441 & 0.0048 \\
\hdashline Mantel-Haenszel Chi-Square & 1 & 0.8749 & 0.3496 \\
\hline Phi Coefficient & - & 0.1742 & - \\
\hdashline Contingency Coefficient & - & 0.1716 & - \\
\hline Cramer's V & - & 0.1742 & - \\
\hline
\end{tabular}

\section{DISCUSSION}

The results of this research are in many cases confirmed not only by representatives of the most important retail chains operating in Slovakia but mainly by the results of research carried out by GfK Slovakia in 2010 (TASR, 2010) and by the results of TNS Slovakia research in 2015 (TNS, 2015). According to these studies, it is possible to say that every Slovak household has its favorite brands for its daily and regular purchases, which it prefers. In some categories of goods, there is a pronounced 
preference for the brand, for example, primacy among products, when buying which customers give a choice to the brand instead of price, hold dairy products, which are purchased on average every third day (TASR, 2010). Also, almost every Slovak ( $98 \%$ of respondents) has already purchased private label products, and the categories in which private labels are preferred over traditional ones include primarily paper products, such as toilet paper, kitchen towels or sanitary towels (TNS, 2015). The most interesting finding of the second mentioned research is that for durable foods (such as sweets, soft drinks, ready meals, pasta and semi-finished products) and foods with shorter expiration dates, there is still no more or less preference for private or traditional brands (they are equally represented), besides classic brands are still more preferred in the case of cosmetics, washing powders, alcoholic beverages, and sometimes coffee and tea.

It can be said that the results obtained from this research, better said from the evaluating questions about the perception of the quality of private label products, what they evoke in consumers, or the reasons for their purchase or non-purchase, confirm the results of research agencies such as TNS Slovakia in 2015 (TNS, 2015), or GFK Slovakia in 2010 (TASR, 2010). Accordingly, our previous research and studies on the subject conducted by other researchers (e.g., Nagyová \& Košičiarová, 2014; Košičiarová et al., 2017) assumed that Slovak consumers buy private labels primarily several times a week or once a week; they buy them mainly for their cost-effectiveness, quality and confidence; and that every Slovak household has "favorite brands" for regular purchases. According to the GFK Slovakia survey, when choosing durable milk, private labels account for approximately $80 \%$ of total consumption. With acidophilic dairy, fresh milk and fresh cheeses, traditional labels prevail over private ones (TASR, 2010).

As mentioned in the Empirical Results section, the last question in the survey focused on what would most affect respondents when purchasing private label products. Based on the question evaluation, it can be said that even though consumers in a modern and globalized world, which is characterized by continuing competitiveness and a dynamic market environment (Smutka et al., 2016), are saturated with traditional communication tools, respectively most often use of online communication tools, respondents will primarily choose the possibility of modern forms of marketing communication, such as online communication, digital marketing, influencer marketing, etc. However, this has not been confirmed and it was realized that even if it is a young generation of consumers, what would most affect the respondent when purchasing private label products are the traditional forms of marketing communication, such as recommendations of acquaintances, tasting and free samples (or $1+1$ sale).

\section{CONCLUSION}

Although the total consumption of milk and dairy products in Slovakia has been relatively negative and declining in recent decades, it is still true that the average consumption of yoghurt (in $\mathrm{kg} / \mathrm{capita}$ ) has increased almost every year - in the last six years it has increased by almost $4 \mathrm{~kg}$. This also explains why yoghurts themselves, both traditionally and privately labeled, have been the subject of research in this paper. The paper focused on the issue of private labels, their perception by the young generation of Slovak consumers (under 25), and, in particular, on the impact of packaging on the purchasing decisions of consumers under the age of 25 in the dairy segment.

An anonymous questionnaire survey was used as the main research method, involving a total of 594 respondents under the age of 25 , followed by a blind test involving a total of 20 respondents from a given age category.

As already mentioned several times, a total of five yoghurt samples, which were identical yoghurts, i.e., yoghurts of traditional brands and their private alternatives, were analyzed in the blind test. The results of this research point to several interesting findings - while just over $26 \%$ of respondents buy private la- 
bels regularly, almost $58 \%$ buy them sporadically. In terms of purchase frequency, respondents buy private labels quite often, as more than $20 \%$ of respondents reported buying them multiple times a week, $18.21 \%$ of respondents reported buying them once a week and almost $18 \%$ of respondents purchased multiple times a month. In terms of the perception of the quality of private label products, what they evoke in consumers, or the reasons for their purchase or non-purchase, it can be said that respondents perceive private label products as products of good and adequate quality (slightly more than $47 \%$ of respondents), most of them, almost $60 \%$, have the impression of adequate quality at a reasonable price; the decisive factor in their purchase is a combination of reasonable price and quality (almost $48 \%$ of respondents), the reasons why they do not buy them are their high price (over $20 \%$ of respondents), poor quality (slightly over $17 \%$ of respondents), and lack of familiarity with their producer (almost $14 \%$ of respondents). Regarding the impact of packaging on respondents' purchasing decisions, it has been found out that although most respondents have no opinion on the packaging of private label products (up to $39 \%$ of respondents), less than $34 \%$ think this packaging is unattractive, and about 33\% think that their packaging does not affect them. This finding was then complemented by the result of a correspondence analysis stating that those respondents who reported that they buy private labels regularly think that private labels have attractive packaging and that packaging does not affect them in their purchasing decision; respondents who buy private labels sporadically think that their packaging is unattractive and that it affects their purchasing decisions; and those respondents who do not buy them do not have an opinion and cannot to asses it. To this one can add the result of a blind test, which takes place in two rounds (without the information on the products tested and with the information on the products tested). Based on the overall assessment of the respondents in the first round of the blind test, the best yoghurts were samples 5 and 3 (in both cases, private label products), in the second round they were samples 5 and 4 (i.e., a private label product and a traditional brand product). Based on the above, it can be said that the boundaries between traditional and private labels are gradually blurring and that the possibilities to increase the attractiveness of private label yoghurts (as we consider them an adequate alternative to traditional brands) can be based on raising awareness among Slovak consumers about private labels and their manufacturers. In many cases, it has been found that Slovak consumers are still hesitant to buy private label products because they have no experience with these products or do not know their real manufacturer.

\section{ACKNOWLEDGMENT}

The paper was supported by the research project GA SUA No. 8/2019 "Private labels as the alternative to purchase", which is solved at the Department of Marketing and Trade, Faculty of Economics and Management, Slovak University of Agriculture in Nitra.

\section{AUTHOR CONTRIBUTIONS}

Conceptualization: Zdenka Kádeková, Ingrida Košičiarová, Vladimír Vavrečka, Milan Džupina.

Data curation: Zdenka Kádeková, Ingrida Košičiarová, Vladimír Vavrečka, Milan Džupina. Formal analysis: Zdenka Kádeková, Ingrida Košičiarová, Vladimír Vavrečka, Milan Džupina. Funding acquisition: Zdenka Kádeková, Ingrida Košičiarová, Vladimír Vavrečka, Milan Džupina. Investigation: Zdenka Kádeková, Ingrida Košičiarová, Vladimír Vavrečka, Milan Džupina.

Methodology: Zdenka Kádeková, Ingrida Košičiarová, Milan Džupina.

Project administration: Zdenka Kádeková, Ingrida Košičiarová.

Resources: Zdenka Kádeková, Ingrida Košičiarová, Vladimír Vavrečka.

Software: Zdenka Kádeková, Ingrida Košičiarová.

Supervision: Zdenka Kádeková, Ingrida Košičiarová, Milan Džupina.

Validation: Zdenka Kádeková, Ingrida Košičiarová, Vladimír Vavrečka, Milan Džupina.

Visualization: Zdenka Kádeková, Ingrida Košičiarová, Vladimír Vavrečka, Milan Džupina.

Writing - original draft: Zdenka Kádeková, Ingrida Košičiarová, Vladimír Vavrečka.

Writing - review \& editing: Zdenka Kádeková, Ingrida Košičiarová. 


\section{REFERENCES}

1. Balcarová, T., Pokorná, J., \& Pilař, L. (2014). The Influence of Children on the Parents Buying Behaviour: Food Purchase in the Czech Republic. Agris on-line Papers in Economics and Informatics, 6(2), 11-19. retrieved from https://www.researchgate.net/ publication/286123717_The_Influence_of_Children_on_the_Parents_Buying_Behavior_Food_Purchase_in_the_Czech_Republic

2. Bulanda, I., Džupina, M., \& Franková, V. (2018a) Consumer Assessment of Selected Food Commodities by Slovak Woman from Generation Y. QUAERE 2018, 174-184.

3. Bulanda, I., Viteková, I., Koprda, T., \& Blahová, B. (2018b) Slovak consumers from generation $\mathrm{Y}$ and their shopping behavior on discount portals. International Scientific Days 2018: "Towards Productive, Sustainable and Resilient Global Agriculture and Food Systems", 275-287. https:// doi.org/10.15414/isd2018.s2-1.01

4. Burt, S. (2000). The strategic role of retail brands in British grocery retailing. European Journal of Marketing, 34(8), 875-890. https://doi. org/10.1108/03090560010331351

5. Clow, K., Baack, D. (2008). Reklama, propagace a marketingová komunikace. Brno: Computer Press.

6. Dudriková, E., Nagyová, M., \& Dičáková, Z. (2017). Survival of Lactobacillus Bulgaricus and Bifidobacterium Animalis in Yoghurts Made From Commercial Starter Cultures During Refrigerated Storage. Potravinarstvo Slovak Journal of Food Sciences, 11(1), 597-601. https://doi.org/10.5219/758

7. Džupina, M., Hodinková, D., \& Kiková, H. (2016). Spoločensky zodpovedné podnikanie ako zdroj hodnôt značky. Nitra: UKF.

8. Euromonitor. (2014). The New Face of Private Label: Global Market Trends to 2018. Retrieved January 10, 2020, from http://blog.euromonitor. com/2014/01/the-new-face-ofprivate-label-globalmarket-trendsto-2018.html

9. Habánová, M., Lorková, M., \& Kopčeková, J. (2010). The con- sumption of acidophylus drinks and yogurts in selected population of pupils in years 2004 and 2008. Potravinárstvo, 4(3), 19-23. https:// doi.org/10.5219/26

10. Herstein, R., \& Gamliel, E. (2004). An Investigation of Private Branding as a Global Phenomenon. Journal of Euromarketing, 13(4), 59-77. https:// doi.org/10.1300/J037v13n04_04

11. Horská, E. (2007). Medzinárodný marketing. Nitra: Slovenská polnohospodárska univerzita.

12. Chimhundu, R. (2011). Private Label Marketing Performance: An Analysis of Historical Trends Using Theories of Cumulative Change and Punctuated Equilibrium. International Journal of Business and Management, 6(8), 58-65. Retrieved from https://www.researchgate. net/publication/266039335_Private_Label_Marketing_Performance_An_Analysis_of_Historical_Trends_Using_Theories_of_Cumulative_Change_and_Punctuated_Equilibrium

13. Janková, G., \& Strbová, E. (2017). Educational aspect of advertising from perception of future marketing experts. 20th International Scientific Conference "Economic and Social Development, 598-609. Retrieved from https://search. proquest.com/openview/db4df022 9aa718f23358d4cddfd6135b/1?pqorigsite $=$ gscholar $\& \mathrm{cbl}=2033472$

14. Kádek, P. (2014). Súčasné dimenzie právnej zodpovednosti v medicíne a zdravotníctveю Bratislava: Wolters Kluwer.

15. Kakkos, N., Trivellas, P., \& Sdrolias, L. (2015). Identifying Drivers of Purchase Intention for Private Label Brands. Preliminary Evidence from Greek Cnsumers. Science Direct. Procedia Social and Behavioral Sciences, 175, 522-528. https://doi. org/10.1016/j.sbspro.2015.01.1232

16. Kaliji, S. A., Mojaverian, S. M., Amirnejad, H., \& Canavari, M. (2019). Factors Affecting Consumers' Dairy Products Preferences. Agris on-line Papers in Economics and Informatics, 11(2), 3-11. https:// doi.org/10.7160/aol.2019.110201
17. Kenton, W. (2018) Customer. Retrieved January 10, 2020 from https://www.investopedia.com/ terms/c/customer.asp

18. Košičiarová, I., Holienčinová, M., \& Nagyová, L. (2014). Knowledge and preference of private label products by Slovak consumer. Improving performance of agriculture and the economy: challenges for management and policy, MVD, 71. Retrieved January 8, 2020, from https://spu. fem.uniag.sk/mvd2014/proceedings/articles/Sedliakova.pdf

19. Košičiarová, I., \& Nagyová, L. (2014). Private label: the chance how to increase the consumer's interest in a proper retail chain. ICABR 2014, 452-467. Retrieved January 19, 2020 from http://www.icabr.com/fullpapers/icabr2014.pdf

20. Košičiarová, I., Nagyová, L., Holienčinová, M., Kádeková, Z., \& Rybanská, J. (2018). Preference and perception of private label products and yoghurts - a case study of Slovak consumers with the age up to 30 years. International Scientific Days 2018: "Towards Productive, Sustainable and Resilient Global Agriculture and Food Systems", 372-390. https:// doi.org/10.15414/isd2018.s2-1.08

21. Košičiarová, I., Nagyová, L., Holotová, M., \& Rybanská, J. (2017). Preference and perception of products and yoghurts labelled by the private label from the side of young Slovak consumers. Managerial Trends in the Development of Enterprises in Globalization ERA, 797-806. Retrieved January 11, 2020 from http://spu.fem.uniag.sk/fem/ ICoM_2017/files/international_scientific_conference_icom_2017

22. Kotler, Ph., \& Keller, K. L. (2007). Marketing management. Praha: Grada Publishing, a.s.

23. Kubicová, L., Predanocyová, K., \& Kádeková, Z. (2019). The importance of milk and dairy products consumption as a part of rational nutrition. Potravinarstvo Slovak Journal of Food Sciences, 13(1), 234243. https://doi.org/10.5219/1050

24. Kumar, N., \& Steenkamp, J.-B (2007). Private Label Strategy: How 
to Meet the Store Brand Challenge. Harvard Business Review Press.

25. Lorincová, S., Hitka, M., Štarchoň, P., \& Stachová, K. (2018). Stratic Instrument for Sustainability of Human Resource Management in Small and Medium-Sized Enterprises Using Management Data. Sustainability, 10(10), 3687. https:// doi.org/10.3390/su10103687.

26. Mach, J., Dvořák, M., \& Hošková, P. (2018). EU Milk and Dairy Market Changes and Impact of Globalisation Trends. Globalization and its socio-economic consequences (Part III. Economic Progress in Post-Soviet Countries) 10.10.2018, 1204-1212.

27. Nagyová, L', \& Košičiarová, I. (2014) Privátne značky: fenomén označovania výrobkov 21. Storočia na európskom trhu. Nitra: SUA.

28. Nielsen. (2018). The Rise and Rise Again of Private Label. Retrieved January 10, 2020 from https://www. nielsen.com/ssa/en/insights/report/2018/the-rise-and-rise-againof-private-label/\#

29. Park City Group. (2000) Private Label. A Store Brand Primer

30. Pilař, L., Kvasničková Stanislavská, K., Gresham, G., Poláková, J., Rojík, S., \& Petkov, R. (2018). Questionnaire vs. Social Media Analysis Case Study of Organic Food. Agris on-line Papers in Economics and Informatics, 10(3), 93-101. Retrieved from https://online.agris.cz/archive $/ 2018 / 3 / 8$

31. PLMA. (2019). Industry news. Private label today. Retrieved January 8, 2020 from https://www.plmainternational.com/industry-news/ private-label-today

32. PLMA. (2020). Industry news. Private label today. Retrieved January 8, 2020 from https://www.plmainternational.com/industry-news/ private-label-today

33. Polakevičová, I. (2015). Application of transactional analysis in marketing research - models of the hierarchy of effects of marketing communication and structural analysis. Prohuman: vedecko-odborný internetový časopis - sociálna práca, psychológia, pedagogika, sociálna politika, zdravotníctvo, ošetrovatelstvo, 7(2), 1-10. Retrieved from https://www.prohuman.sk/ psychologia/application-transactional-analysis-marketing

34. Polakevičová, I., \& Uhríková,P. (2015). Perception of the erotic theme of Dolce \& Gabbana and Calvin Klein print advertisement in terms of gender differentiation of the generation Y customer segment. Prohuman: vedecko-odborny internetový časopis - sociálna práca, psychológia, pedagogika, sociálna politika, zdravotníctvo, ošetrovatelstvo, 7(10), 1-4. Retrieved from https://www.prohuman.sk/ psychologia/perception-erotictheme-dolce-gabbana-and-calvinklein-print-advertisement-termsgender-differentiation

35. Rajt, Š. (2000). Marketing, charakteristika, stratégia, proces. Bratislava: Sprint.

36. Ruiz-Real, J. L., Gázquez-Abad, J. C., Esteban-Millat, I., \& Martinez-Lopez, F. J. (2016). Betting exclusively for private labels: Could it have negative consequences for retailers? Spanish Journal of Marketing - ESIC, 11(12). https://doi.org/10.1016/j. sjme.2016.12.004

37. Smith, R. K., \& Bashaw, E. R. (2009). Using Information Processing To Build A Private Label Brand In Big Emerging Markets. International Business \& Economics Research Journal - April 2009, 4(8), 27-42. https:// doi.org/10.19030/iber.v8i4.3123

38. Smutka, L., Svatoš, M., Tomšík, K., \& Sergienko, O. I. (2016). Foreign trade in agricultural products in the Czech Republic. Agricultural Economics (AGRICECON), 62(1), 9-25. https://doi.org/10.17221/18/2015AGRICECON

39. Statistics. (2019) Spotreba vybraných druhov potravín na 1 obyvatela. Retrieved January 18, 2020 from http:// datacube.statistics.sk/\#!/view/sk/ VBD_SLOVSTAT/ps2041rs/Spotreba\%20vybran\%C3\%BDch\%20 druhov\%20potrav\%C3\%ADn\%20 na\%201\%20obyvate $\% C 4 \% B E a \% 20$ \%5Bps2041rs\%5D

40. Světlík, J., \& Bulanda, I. (2019). Adolescents Perception of the Commercial Advertising in Slovakia. Economic and Social Development, 201-209. Retrieved from https:// search.proquest.com/openview/7d1
$832 \mathrm{f} 43 \mathrm{e} 2 \mathrm{a} 48112220857 \mathrm{f} 908 \mathrm{~d} 2 \mathrm{cbf} / 1$ ? pq-origsite $=$ gscholar $\& \mathrm{cbl}=2033472$

41. Šedík, P., Horská, E., SkowronGrabowska, B., \& Illés, Cs. B.

(2018a). Generation marketing in strategic marketing management: case study of honey market. Polish Journal of Management Studies, 18(1), 326-337. Retrieved from https://www.researchgate.net/ publication/330026423_Generation_marketing_in_strategic_marketing_management_Case_study_ of_honey_market

42. Šedík, P., Kňazovická, V., Horská, E., \& Kačániová, M. (2018b). Consumer sensory evaluation of honey across age cohorts in Slovakia. Potravinarstvo Slovak Journal of Food Sciences, 12(1), 673-679. https://doi.org/10.5219/938

43. Štarchoň, P., \& Weberová, D. (2019). Spontaneous Brand Awareness and Consumer Attitudes to Brands in the Czech Republic and Slovakia. Strategic Innovative Marketing. IC-SIM 2017, 151-158. https://doi. org/10.1007/978-3-030-16099-9_20

44. TASR. (2010). PRIESKUM: Predaj značkových tovarov si udržal postavenie aj $v$ čase krízy. Retrieved January 18, 2020 from http://www. edb.sk/sk/spravy/prieskum-predajznackovych-tovarov-si-udrzal-postavenie-aj-v-case-krizy-a2398.html

45. TNS. (2015). Oblúbenost privátnych značiek na Slovensku rastie.

46. Tvrdoň, O., \& Přibyl, M. (2004). Význam maloobchodních značek pro zvýšení prodeje zboží. Acta Univerisitatis Agiculturae et Silviculturae Mendelianae Brunensis, 52(3), 145-156. Retrieved from https:// acta.mendelu.cz/media/pdf/actaun_2004052030145.pdf

47. VÚEPP. (2018) Mlieko. Retrieved January 15, 2020, from http://www. vuepp.sk/dokumenty/komodity/2018/Mlieko_nov_18.pdf

48. Witek, L. (2016). Influence of Sociodemographic Characteristics of Consumers on Attitudes Towards Cause Related Marketing. Acta Universitatis Agriculturae et Silviculturae Mendelianae Brunensis, 64(6), 2173-2182. https://doi.org/10.11118/ actaun 201664062173 